\title{
Penggunaan Konsep Flat Design pada Markers Semaphore Augmented Reality
} Rizky Arif Fauzi, Luky Rafi Anuggilarso, Awal Rafi Hardika, Dhanar Intan Surya Saputra

Program Studi Teknik Informatika, STMIK Amikom Purwokerto, Jl. Let. Jend. Pol. Sumarto Watumas Purwokerto, Kabupaten Banyumas, Telp. (0281) 623321

\section{KEYWORDS}

augmented realty, flat design, markers, semaphore

\section{CORRESPONDENCE}

Phone: +6289501123808

E-mail: rizkyarif92@gmail.com

\section{PENDAHULUAN}

Penggunaan desain grafis dalam segala hal sudah tidak dapat lagi dipungkiri. Hampir segala kebutuhan dalam penyampaian informasi membutuhkan adanya desain grafis. Hal ini membuat pentingnya memikirkan konsep dan penerapan fungsi serta prinsip-prinsip desain serta elemen-elemen lain yang melekat pada desain itu sendiri seperti tulisan, jenis huruf, warna hingga bentuk dari penggambaran objek yang akan ditampilkan.

Adanya unsur nilai estetika dalam sebuah desain grafis juga dipandang perlu. Tentu saja setiap karya desain grafis mengandung nilai estetika, dimana estetika tersebut tidak sebatas yang terlihat, namun juga yang tidak terlihat secara kasat mata. Nilai estetika atau keindahan menjadi hal utama yang dapat menentukan suatu hasil karya agar dapat dinikmati oleh hampir seluruh panca indera manusia, seperti penglihatan ataupun pendengaran, hingga perasaan dan jiwa. Keindahan itu sendiri sangat berkaitan erat dengan segala sesuatu yang mencakup kesatuan (unity), keselarasan (harmony), kesetangkupan (symmetry), keseimbangan (balance), dan perlawanan (contrast) [1]. Penggunaan elemen desain yang tepat dapat mempengaruhi emosi dan reaksi pengunjung maupun target pengguna dalam membuat keputusan [2]. Untuk itu, karakter, simbol, dan elemen desain lainnya seperti warna yang dipilih, jenis font dan gambar harus dapat menunjukkan kepribadian merek, organisasi atau informasi yang akan disampaikan [3].

Perkembangan teknologi dan komputer membawa dampak diberbagai hal, tidak terkecuali pada bidang desain grafis. Hal ini ditunjukkan dengan adanya perkembangan model desain user interface (UI) dari berbagai tampilan sistem operasi komputer, smartphone hingga aplikasi yang ada atau terpasang pada perangkat tersebut. Adapun trend desain bergeser menjadi lebih simpel. Jika sebelumnya banyak konsep desain yang mengusung konsep Rich Design dengan memberikan efek bevels, drop shadow, atau gradien serta efek lainnya, maka perkembangan trend beralih dengan mengusung konsep Flat Design.

Flat Design adalah salah satu gaya desain yang menekankan unsur minimalis, 2 dimensi (2D), dan perpaduan warna-warna yang cerah. Menekankan pada unsur fungsionalitas dan kegunaan dengan desain yang bersih tanpa ada bevel, bayangan (shadow), tekstur dan berfokus pada tipografi [4]. Penggunaan elemen yang memberikan ilusi 3 dimensi (3D) disajikan dengan sangat minimalis [5].

Penggunaan flat design tidak hanya didasarkan akan desain yang minimalis saja namun juga adanya pengaruh fungsionalitas dari 
desain itu sendiri terhadap user. Tampilan desain pada user interface aplikasi dapat mempengaruhi banyak hal, bahkan pada hasil penelitian menyebutkan bahwa setiap pengguna (user) mengharapkan tampilan desain antarmuka pada aplikasi dengan kategori user experience yang memuaskan [6]. Data yang disajikan oleh Google sebanyak $67 \%$ (enam puluh tujuh persen) pengguna internet kemungkinan akan melakukan transaksi jika website yang mereka kunjungi adalah website bertampilan user friendly. Sebaliknya, sebanyak $61 \%$ (enam puluh satu persen) pengguna akan meninggalkan website dengan desain yang tidak user friendly [7]. Hal ini tentu saja memberikan gambaran bahwa pentingnya desain sangat berbengaruh terhadap hasil akhir dari sebuah informasi yang tersampaiakan hingga sebuah produk dapat dijual atau tidak.

Pada penelitian ini kami menerapkan konsep flat design yang digunakan untuk pembuatan desain markers semaphore augmented reality. Semaphore Augmented Reality atau yang disebut sebagai aplikasi SERSAN, merupakan inovasi media pembelajaran materi kepramukaan. Dalam aplikasi SERSAN mengandung animasi semaphore, lagu-lagu pramuka dan buku saku pramuka digital. SERSAN akan dapat membantu proses pembelajaran dan sebagai media pendukung proses belajar mengajar dalam melaksanakan kegiatan Pramuka [8]. SERSAN akan menampilkan objek 3D berupa animasi gerakan Semaphore yang disajikan dalam konten augmented reality (AR). Teknologi AR atau Realitas Tertambah merupakan integrasi antara elemen digital yang ditambahkan ke dalam ruang dunia nyata (data real-world) serta dapat mengikuti keadaan lingkungan yang ada pada dunia nyata tersebut [9]. Inovasi dan pemanfaatan teknologi terkini seperti AR, VR dan berbagai aplikasi mobile learning semakin berkembang dan dapat diterapkan dalam berbagai aspek proses pembelajaran, tidak terkecuali pada kegiatan kepramukaan [10], [11] .

Arsitektur sistem pada AR bekerja berdasarkan adanya deteksi citra, citra yang digunakan yaitu marker. Kamera pada smartphone yang telah dikalibrasi akan melakukan pendeteksian terhadap marker yang diberikan, jika marker tersebut dikenali maka pola akan ditandai apakah sesuai dengan database pada aplikasi. Bila sesuai maka marker akan digunakan untuk menampilkan objek yang telah dibuat. Objek dapat berupa video, animasi, objek 2D atau 3D, location based, dan objek lain yang telah diatur [12].

Penelitian ini menerapkan penggunaan konsep flat design untuk melakukan desain markers SERSAN dengan harapan tidak hanya objek AR saja yang mudah dinikmati oleh pengguna, namun informasi yang disajikan melalui desain juga dapat tersampaikan kepada pengguna dalam belajar Semaphore.

\section{METODE}

Dalam penelitian ini, kami menyajikan dalam bentuk penelitian kualitatif. Diharapkan markers yang digunakan pada aplikasi SERSAN nantinya tidak hanya menyajikan gambar saja sebagai database konten AR, namun sesuai dengan hasil informasi telah didapatkan dan diolah menjadi sebuah bentuk desain. Adapun sumber informasi diambil dari siswa atau peserta didik
Ekstrakurikuler Pramuka, Pelatih atau Pembina Pramuka dan Programmer aplikasi SERSAN.

Hasil data yang didapatkan dari wawancara kemudian dianalisis dan diolah dalam bentuk desain markers SERSAN menggunakan konsep Flat Design. Adapun topik wawancara difokuskan pada pengetahuan tentang Semaphore dan proses pembelajarannya. Peneliti juga melakukan kajian literatur berupa pengumpulan analisis sumber referensi, baik dari buku, artikel maupun jurnal yang berkaitan dengan penelitian. Selain itu, peneliti juga melakukan observasi dan dokumentasi untuk menemukan data secara mendalam, observasi dilakukan pada saat proses kegiatan belajar mengajar kegiatan kepramukaan.

Adapun tahapan yang peneliti lakukan terdiri dari beberapa tahapan, meliputi pengumpulan data, gagasan desain yang mencakup pembuatan desaian berdasarkan prinsip, filosofi, fungsi dan estetika desain menggunakan konsep flat design dilanjutkan dengan review design untuk penilaian maupun perubahan desain hingga tahap akhir berupa keputusan desain akhir yang nantinya akan digunakan. Tahapan-tahapan tersebut dapat ditampilkan dalam gambar 1 berikut ini.

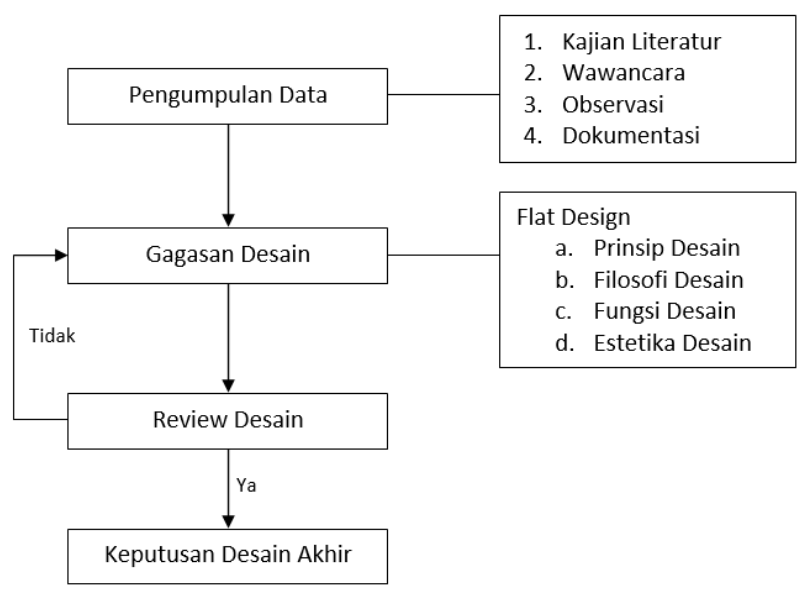

Gambar 1. Alur Penelitian

\section{HASIL DAN PEMBAHASAN}

Berdasarkan tahapan penelitian yang telah disusun, maka pada tahap kajian literatur, telah didapatkan beberapa data yang nantinya akan disusun dan diolah dalam bentuk desain. Adapun data literatur dari kepramukaan dan Semaphore yang didapatkan yaitu:

\section{Pramuka}

Gerakan Pramuka atau Kepanduan di Indonesia telah dimulai sejak tahun 1923 yang ditandai dengan didirikannya Nationale Padvinderij Organisatie (NPO) di Bandung. Gerakan Pramuka Indonesia adalah nama organisasi pendidikan nonformal yang menyelenggarakan pendidikan kepanduan di Indonesia. Kata "Pramuka" merupakan singkatan dari Praja Muda Karana, yang memiliki arti Jiwa Muda yang Suka Berkarya [13]. Gerakan pramuka menyelenggarakan pendidikan kepramukaan sebagai cara mendidik kaum muda dengan bimbingan orang dewasa. Dalam mengamalkan isi dari satya itu berbeda untuk golongan atau tingkatannya yaitu: 
Siaga (usia 7 - 10 tahun), mengamalkan Dwi Satya dan Dwi Darma.

Penggalang (usia 11 - 15 tahun), mengamalkan Tri Satya serta menepati Dasa Darma.

Penegak (usia 16 - 20 tahun), Pandega (usia 21 - 25 tahun) serta Anggota Dewasa, mengamalkan Tri Satya, menolong sesama hidup, dan ikut serta membangun masyarakat, serta menepati Dasa Darma [14].

\section{Semaphore}

Semaphore, merupakan Sandi yang menggunakan bendera/ tangan/ batang/ dayung untuk menyampaikan/ menerima pesan. Caranya penyampai atau penerima pesan menggerakan tangan sesuai dengan kode tertentu. Semaphore merupakan suatu keahlian yang harus dimiliki oleh seorang Pramuka, dalam mempelajari semaphore membutuhkan waktu pemahaman dan latihan, dibutuhkan daya ingat dan pemahaman yang lebih [15]. Dalam prakteknya untuk mempelajari gerakan semaphore dibutuhkan seseorang dalam mengirim kode sempahore dan orang lain untuk dapat menterjemahkan pesan yang diterimanya. Gerakan semaphore dari huruf $\mathrm{A}$ hingga $\mathrm{Z}$ yang didapatkan dari hasil pengumpulan data, seperti terlihat pada gambar 2 .

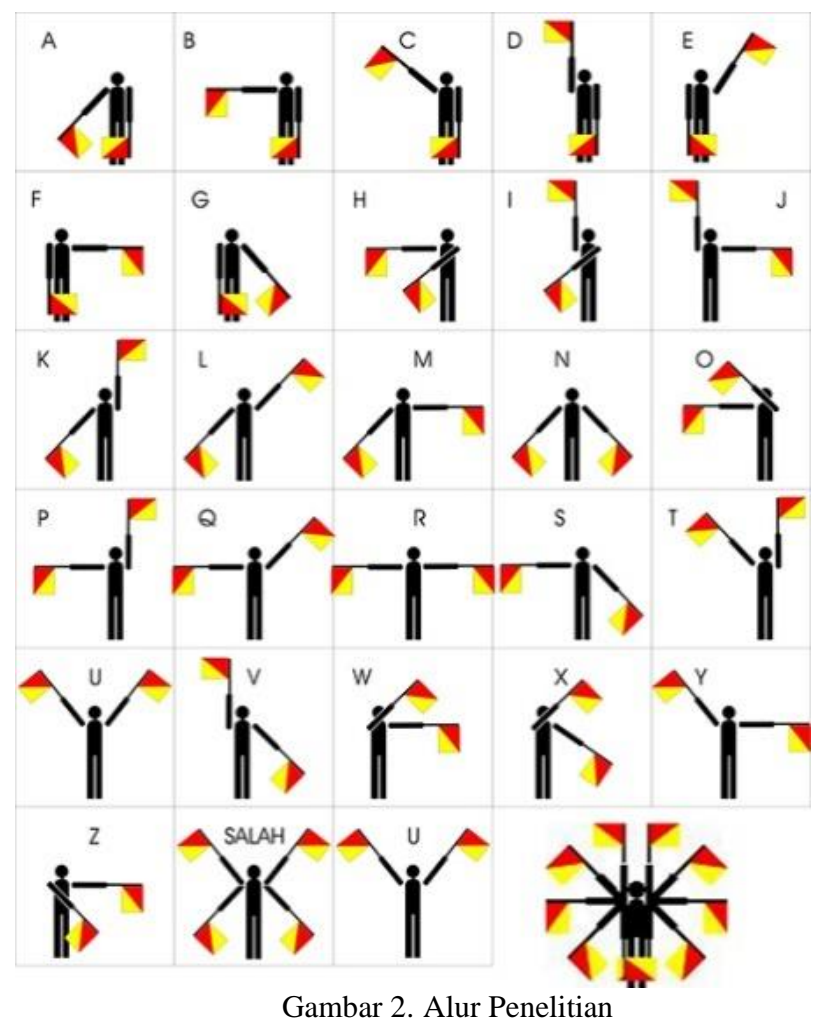

\section{Tahapan Desain Markers}

Ketika data yang didapatkan cukup, maka tahapan berikutnya adalah masuk dalam tahapan gagasan desain. Adapun pada tahapan gagasan desain, markers yang akan dibuat disajikan dalam 2 (dua) muka, yaitu bagian depan yang berisi gambar Semaphore dan bagian belakang yang berisi gambar sampul SERSAN. Pada bagian depan akan dibuat desain Semaphore dari huruf $A$ hingga huruf $Z$ atau sebanyak 26 (dua puluh enam) desain, sedangkan pada sisi bagian belakang semua desain sama. Konten disajikan dalam bentuk Flat Design, dengan informasi yang ditampilkan dalam desain, baik desain bagian depan maupun belakang meliputi :

Logo Aplikasi SERSAN

Karakter Pramuka

Bendera Sempahore

Abjad dari A - Z

Pembuatan karakter Pramuka dibuat berdasarkan referensi dari tokoh Pramuka lengkap dengan atribut dan seragamnya, termasuk gerakan anggota Pramuka saat memperagakan Semaphore.

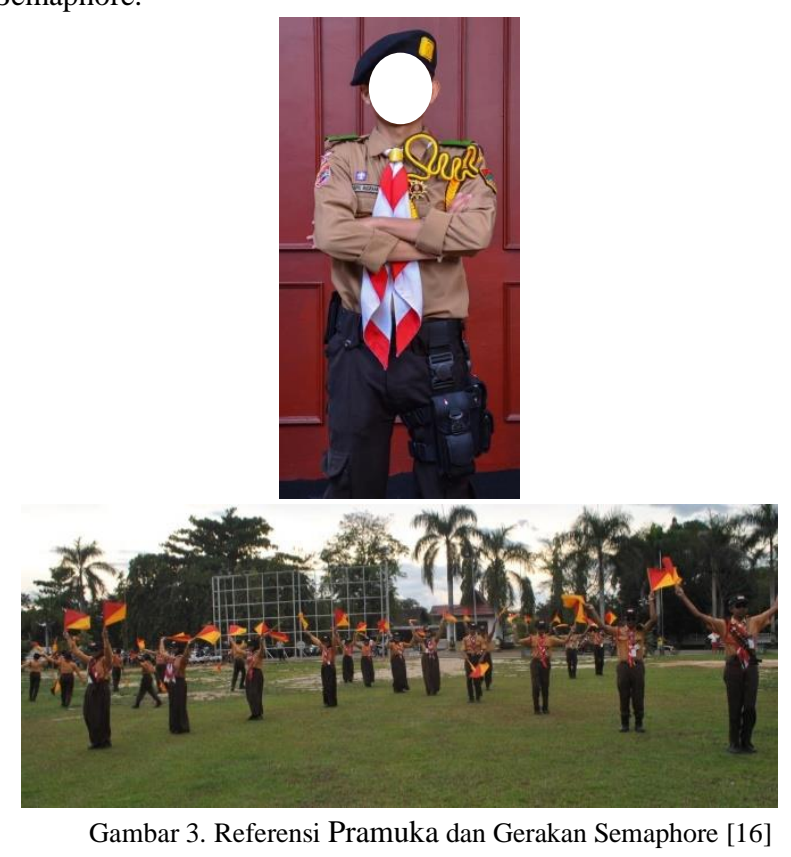

Hasil olahan desain pramuka menggunakan konsep flat design berdasarkan referensi yang didapatkan.

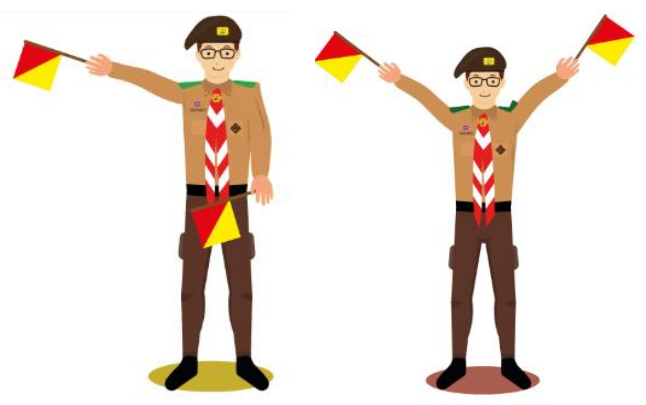

Gambar 4. Hasil Desain Karakter Pramuka dengan Konsep Flat Design

Hasil olahan desain karakter Pramuka kemudian disatukan dalam olahan desain pada masing-masing huruf dari A sampai huruf Z, kemudian gambaran dari gerakan Semaphore untuk dijadikan desain markers halaman depan, seperti pada Gambar berikut ini. 


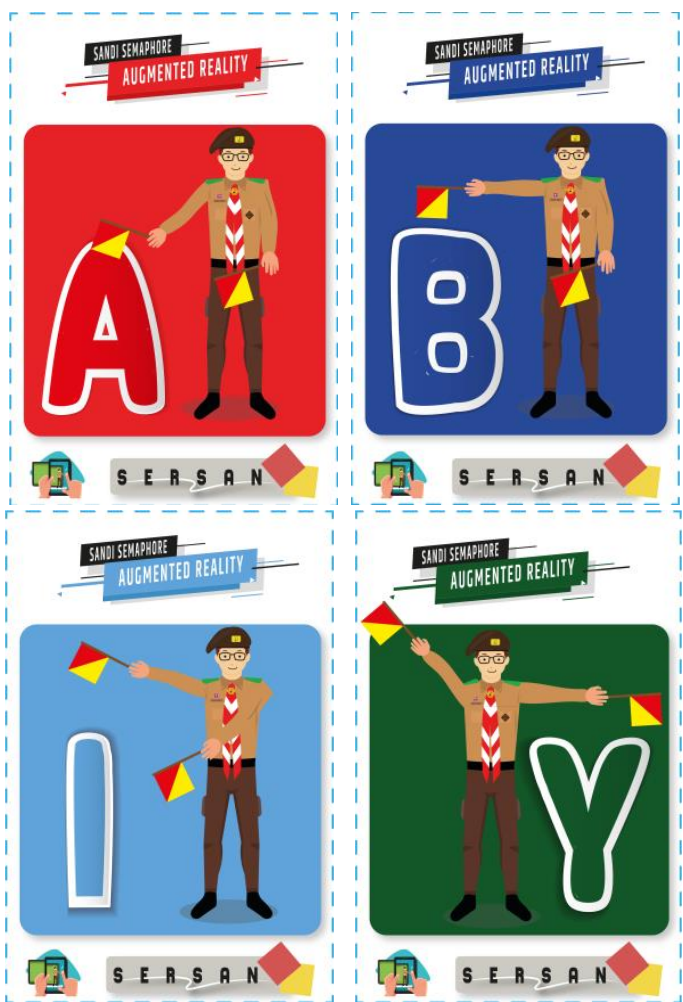

Gambar 5. Hasil Desain Markers Bagian Depan untuk Huruf

Desain markers halaman belakang dibuat terpisah dengan model desain satu untuk semua huruf dengan konsep yang sama, seperti pada gambar berikut ini.

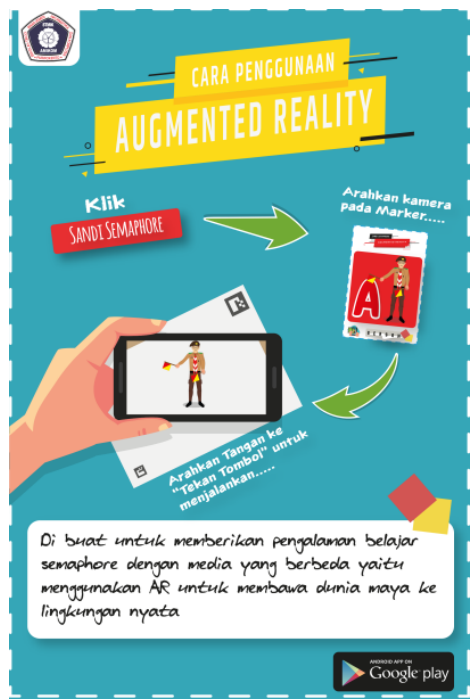

Gambar 6. Hasil Desain Markers Bagian Belakang

Ketika tahapan desain telah selesai, maka dilanjutkan untuk review desain yang diserahkan kepada :

Pembina Pramuka untuk melihat konten posisi gerakan Semaphore dari desain yang dibuat sudah sesuai dengan arahan atau petunjuk dari sumber data.

Programmer SERSAN untuk sinkronisasi database objek dan animasi 3D dari gerakan semaphore, terlihat pada gambar 7, maka objek telah sesuai dengan kondisi yang diinginkan.

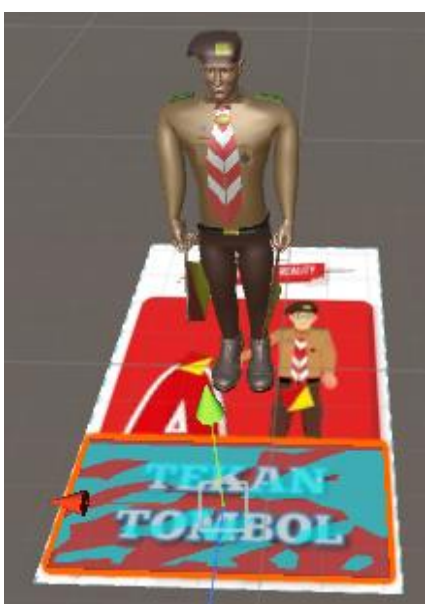

Gambar 7. Hasil Review Desain dengan Programmer SERSAN

Tahapan terakhir dari hasil desain markers SERSAN ketika semua huruf telah selesain di desain, maka dilakukan review dan evaluasi. Tahapan review dilakukan dengan pencocokan gambar dengan database augmented reality yang nantinya akan muncul sebagai objek. Setelah terkumpul sebanyak 26 huruf dari A sampai $\mathrm{Z}$ maka, desain berikutnya adalah desain packaging untuk kotak markers, desain packaging seperti terlihat pada gambar berikut.

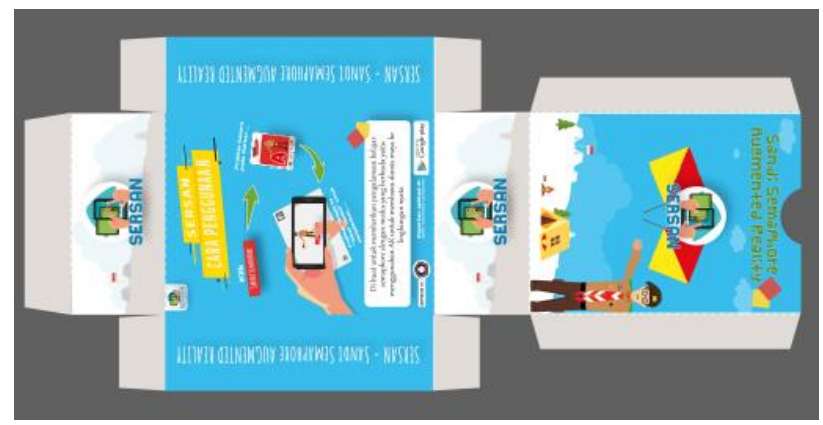

Gambar 8. Hasil Desain Packaging Markers

Hasil akhir dari desain ini kemudian dilakukan pencetakan yang nantinya akan berwujud kartu sebagai Markers SERSAN, pencetakan dilakukan dengan jumlah sesuai dengan kebutuhan dari produksi dan distribusi aplikasi SERSAN, seperti pada gambar berikut.

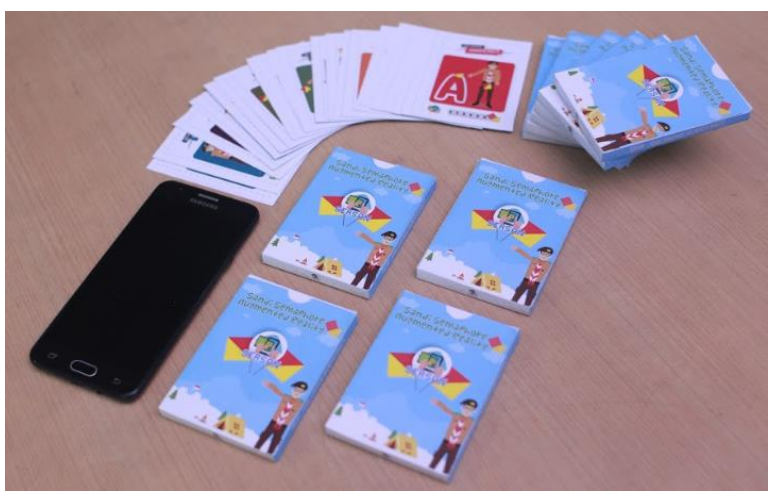

Gambar 9. Hasil Desain Kartu Markers dan Packaging yang sudah diproduksi 


\section{KESIMPULAN}

Hasil akhir dari desain markers SERSAN telah dapat digunakan sebagai bagian dari aplikasi AR, dan dapat digunakan sebagai pembacaan database pada konten animasi 3D dari objek Semaphore yang dimunculkan. Untuk hasil akhir markers sudah dapat diproduksi dalam bentuk kartu dan kemasannya. Masih terdapat beberapa kekurangan dalam sisi desain karakter, diantaranya pada saat gambar karakter Pramuka memegang bendera tangan masih terbuka dan tidak menggenggam tongkat bendera, harapannya untuk desain berikutnya dapat lebih didetailkan. Kemudian pada pengembangan berikutnya markers dapat disusun dalam bentuk multimarkers pada aplikasi SERSAN.

\section{UCAPAN TERIMA KASIH}

Penulis mengucapkan terima kasih yang sebesar-besarnya kepada Direktorat Jenderal Pembelajaran dan Kemahasiswaan, Kementerian Riset, Teknologi, dan Pendidikan Tinggi yang telah mendanai kegiatan Program Kreativitas Mahasiswa (PKM) Bidang Karsa Cipta (KC) dan STMIK Amikom Purwokerto yang telah memberikan kesempatan kepada kami untuk dapat mengikuti Program Kreativitas Mahasiswa (PKM) tahun 2019.

\section{DAFTAR PUSTAKA}

[1] B. Irawan and P. Tamara, Dasar-Dasar Desain. Jakarta: Griya Kreasi, 2013.

[2] S. Wang and V. T. Hoa, "An Application of Software Technology towards an Effective Web Design," Int. J. Eng. Technol., vol. 5, no. 2, 2013.

[3] P. Kotler and G. Armstrong, "Prinsip-prinsip Pemasaran," in 8, 8th ed., Jakarta: Erlangga, 2012.

[4] A. E. Larasati, "Apa Saja Kelebihan dan Kekurangan Flat Design?," 2018. [Online]. Available: https://idseducation.com/articles/apa-saja-kelebihan-dankekurangan-flat-design/. [Accessed: 03-Jul-2019].

[5] A. L. Turner, "The history of flat design: How efficiency and minimalism turned the digital world flat," 2014. [Online]. Available: https://thenextweb.com/dd/2014/03/19/history-flatdesign-efficiency-minimalism-made-digital-world-flat/. [Accessed: 03-Jul-2019].

[6] S. Fauzia, F. Eka, U. Syaripudin, and Y. Ichsani, "Perancangan Prototype Tampilan Antarmuka Pengguna Aplikasi Web Kamardagang.Com Dengan Teknik Flat Design Pada Pt. Selaras Utama Internasional," J. Tek. Inform., vol. 9, no. 2, pp. 148-157, 2019.

[7] "Hasil Survei Penetrasi dan Perilaku Pengguna Internet Indonesia 2018," Asosiasi Penyelenggara Jasa Internet Indonesia, 2019. [Online]. Available: https://apjii.or.id/content/read/39/410/Hasil-Survei-Penetrasidan-Perilaku-Pengguna-Internet-Indonesia-2018.

[8] R. A. Fauzi, L. R. Anuggilarso, A. R. Hardika, and D. I. S. Saputra, "SERSAN (Semaphore Multi Marker Augmented Reality) : Purwarupa untuk Media Pembelajaran Semaphore," in Seminar Nasional FKIP Universitas Tidar 2019, 2019.

[9] R. E. Saputro and D. I. S. Saputra, "Pengembangan Media Pembelajaran Mengenal Organ Pencernaan Manusia Menggunakan Teknologi Augmented Reality," J. Buana Inform., vol. 6, no. 2, 2015.

[10] F. S. Riyadi, A. Sumarudin, and Munengsih Sari Bunga,
“Aplikasi 3D Virtual Reality Sebagai Media Pengenalan Kampus Politeknik Negeri Indramayu Berbasis Mobile," $J$. Inform. dan Komput., vol. 2, no. 2, pp. 75-82, 2017.

[11] Berlilana, D. I. S. Saputra, and S. W. Widayat, "Mobile Application 'Pramuka dalam Android' sebagai Media Pendukung Pembelajaran Materi Pramuka," in Seminar Nasional Informatika (SEMNASIF) 2015, 2015.

[12] D. I. S. Saputra, E. Utami, and A. Sunyoto, "Penerapan Mobile Augmented Reality Berbasis Cloud Computing Pada Harian Umum Radar Banyumas," in Seminar Nasional Informatika (SEMNASIF) 2015, 2015.

[13] Buku Panduan Museum Sumpah Pemuda. Jakarta: Museum Sumpah Pemuda, 2009.

[14] A. Zubair, Satya: Ragam Intisari Kepramukaan Super Lengkap. Medan: Perdana Publishing, 2014.

[15] S. Alfino, "Rancang Bangun Alat Peraga Sandi Semaphore dan Sandi Morse Berbasis Mikrokontroler Arduino Mega 2560," Universitas Lampung, 2018.

[16] Eka, "Kamad Lantik Pramuka Penggalang," 2018. [Online]. Available: https://kalsel.kemenag.go.id/cetak/518789/KamadLantik-Pramuka-Penggalang. [Accessed: 03-Jul-2019]. 